DOI: https://doi.org/10.47405/mjssh.v5i7.444

\begin{tabular}{|c|c|}
\hline 1. 1.54 & Malaysian Journal of Social Sciences and Humanities (MJSSH) \\
\hline $\begin{array}{c}\text { Malaysian Journal of } \\
\text { solal sciences and }\end{array}$ & Volume 5, Issue 7, July 2020 \\
\hline (MJ-SSH) & e-ISSN : 2504-8562 \\
\hline & $\begin{array}{l}\text { Journal home page: } \\
\text { www.msocialsciences.com }\end{array}$ \\
\hline
\end{tabular}

\title{
Perkembangan Kemahiran Berfikir Kritis Melalui Pembelajaran STEM Berasaskan Robot (Outside of School Time) di Luar Waktu Sekolah di Sekolah Menengah Daerah Tuaran, Sabah
}

\author{
Fetty Shamy Lin Yahaya', Denis Lajium ${ }^{1}$ \\ ${ }^{1}$ Fakulti Psikologi dan Pendidikan, Universiti Malaysia Sabah (UMS) \\ Correspondence: Fetty Shamy Lin Yahaya (fettyslgold@gmail.com)
}

\begin{abstract}
Abstrak
Pelan Pembangunan Pendidikan Malaysia (PPPM) 2013-2025 telah mendorong transformasi kurikulum pendidikan untuk menekankan dengan lebih lanjut mengenai konsep Kemahiran Berfikir Aras Tinggi (KBAT), yang bertujuan untuk melahirkan pelajar yang mempunyai pemikiran yang lebih kritis untuk bersaing di peringkat antarabangsa. Pembelajaran Sains, Teknologi, Kejuruteraan dan Matematik (STEM) yang boleh digunakan sebagai strategi pembelajaran untuk membina kemajuan dari pengetahuan semasa ke pemikiran aras tinggi. Sesi pembelajaran STEM telah menghubung jalinkan pengajaran dan pembelajaran yang menggabungkan kemahiran berfikir aras tinggi dan kaedah pembelajaran untuk menggalakkan kemahiran berfikir kritis yang dijalankan secara pembelajaran STEM Berasaskan Robot (Outside of School Time) di luar waktu sekolah menengah Daerah Tuaran, Sabah. Kumpulan fokus terdiri daripada 6 orang daripada 24 peserta pelajar tingkatan 2 dan 4 guru sekolah menengah daripada daerah Tuaran, Sabah. Kajian ini adalah berbentuk kualitatif yang menganalisis temu bual kumpulan fokus dan guru. Peserta melalui pembelajaran STEM bersama tugasan "mind-on" dan "hand-on". Kajian ini bertujuan untuk meneroka perkembangan kemahiran berfikir kritis secara mendalam melalui pembelajaran dan pengajaran berasaskan penyelesaian masalah. Kajian telah mengenal pasti disposisi dominan elemen kemahiran berfikir kritis di bawah tema utama iaitu menganalisis, menilai dan mereka cipta dalam penyelesaian masalah. Pembelajaran STEM Berasaskan Robot merangsang pembelajaran bermakna, meningkatkan interaksi bermakna dan mengembangkan kemahiran pemikiran kritis. Implikasi kajian ini menjurus kepada penerokaan pengetahuan yang lebih mendalam terhadap perkembangan disposisi dominan elemen kemahiran berfikir kritis menerusi pembelajaran STEM Berasaskan Robot.
\end{abstract}

Kata kunci: kemahiran berfikir kritis, penyelesaian masalah, STEM

\section{Development of Critical Thinking Skills Through Outside of School Time Robot Based STEM Learning in Secondary School of Tuaran District, Sabah}

\begin{abstract}
Malaysian Education Development Plan or Pelan Pembangunan Pendidikan Malaysia (PPPM) 20132025 has prompted the transformation of Malaysian education curriculum to further emphasize on the concept of high order thinking skills (HOTS), which aims to produce more students with better critical thinking skill to compete internationally. The use of Science, Technology, Engineering, and Mathematics (STEM) education can be used as a learning strategy to enhance on going progress to propel from the understanding of knowledge to application of high order thinking upon knowledge
\end{abstract}


gain. In this study, Outside of School Time Robot based STEM learning session combines high order thinking skills and STEM learning strategy to promote critical thinking skill. The focus group comprises students and secondary school teachers selected from the district of Tuaran, Sabah. Outside of School Time Robot based STEM learning was infused with "mind-on" and "hand-on" problem solving assignments. This paper was conducted quantitatively by analyzing interviews from 6 members of focus group and 4 teachers. The study was aimed to explore in depth the development of dominant elements of critical thinking skill under STEM learning strategy. Main themes emerged from this study are the dominant disposition of critical thinking skill developed through out the learning session which included analyzing, evaluation and creating problem solving. This learning session stimulates meaningful learning, enhancing meaningful interaction and developing critical thinking skill at the same time. The implication of this study is geared towards gaining more in depth understanding of the development of dominant disposition of critical thinking skill through Outside of School Time Robot based STEM learning.

Keywords: critical thinking skill, problem solving, STEM

\section{Pengenalan}

Pelan Pembangunan Pendidikan Malaysia (PPPM) 2013-2025 telah menggariskan lima aspirasi sistem pendidikan Malaysia bagi memastikan pelajar Malaysia dapat bersaing di peringkat antarabangsa. Lima aspirasi tersebut ialah akses, kualiti, ekuiti, perpaduan dan kecekapan. Berdasarkan prinsip pendidikan untuk semua, semua anak di Malaysia berhak mendapat akses yang sama dengan pendidikan berkualiti dan memastikan semua pelajar memenuhi standard minimum, dan lulus untuk mata pelajaran teras Bahasa Malaysia, Bahasa Inggeris, matematik, Sains, sejarah, dan pendidikan Islam atau pendidikan moral di akhir Tingkatan 5. Semua pelajar di Malaysia mempunyai peluang untuk mendapatkan pendidikan berkualiti yang setaraf dengan sistem pendidikan prestasi tinggi negara lain. Untuk mencapai matlamat ini, sistem pendidikan Malaysia perlu dipertingkatkan untuk mencapai prestasi yang lebih baik selaras dengan tahap pendidikan negara-negeri lain mengikut piawaian antarabangsa. Peningkatan ini termasuk bidang seperti matematik, Sains dan Bahasa Inggeris, kemahiran aplikasi, penilaian dan penyelesaian masalah. Aspirasi Malaysia adalah untuk menjadi antara tiga negara teratas dari segi prestasi berdasarkan penilaian antarabangsa seperti trend dalam kajian matematik dan sains (TIMSS) dan program penilaian pelajar antarabangsa (PISA) dalam masa 15 tahun.

Namun begitu, pola sistem pendidikan di Malaysia hari ini masih berorientasikan peperiksaan. Kaedah pengajaran dan pembelajaran di dalam bilik darjah kurang berfokus terhadap pemahaman mendalam pelajar tetapi lebih menekankan hasil daripada aktiviti menghafal yang tidak merangsang pemikiran pelajar. Peperiksaan yang bersifat summatif dan regimental membuat minda pelajar kurang mampu untuk menjana idea atau pemikiran baru atau untuk berfikir luar daripada garis panduan dan norma. Ini membawa pelajar sangat bergantung kepada ramalan soalan dan teknik menjawab untuk mendapatkan keputusan cemerlang dalam peperiksaan (Baharin, Kamarudin \& Manaf, 2018).

Tambahan lagi, dengan menggunakan TIMMS dan PISA sebagai penandaarasan antarabangsa prestasi pelajar Malaysia terhadap keupayaan kognitif dan pengetahuan pelajar berumur 14 tahun dalam sains, matematik dan kadar kebolehan membaca mendapati bahawa pelajar Malaysia mempunyai penguasaan yang rendah dalam kemahiran penyelesaian masalah yang memerlukan kemahiran interpretasi, refleksi dan penilaian dalam sains dan matematik berdasarkan kehidupan sebenar (Laporan Kajian Selidik TIMMS dan PISA Malaysia, 2013). Menurut Nik Pa (2014), pencapaian kurang memberangsangkan negara dalam TIMSS dan PISA dipercayai adalah akibat daripada amalan pendidikan sains dan matematik di Malaysia yang kurang memberikan fokus terhadap strategi penyampaian PdP demi mencapai keberkesanan PdP pelajar di dalam kelas.

Masalah ini turut dikaitkan dengan pelajar Malaysia yang kurang menguasai kemahiran berfikir dan lemah dalam penyelesaian masalah (Abdullah et al., 2019). Keputusan tahun demi tahun telah mendedahkan jurang prestasi pelajar dalam literasi sains, matematik dan keupayaan kognitif aras tinggi 
(Chong, Wong \& Abdul Halim, 2018). Oleh yang demikian, penekanan keperluan kemahiran berfikir terutamanya kemahiran berfikir kritis adalah amat wajar diberi perhatian yang khusus.

Akibat daripada tekanan era globalisasi dan pembangunan sistem pendidikan terkini, Kementerian Pelajaran Malaysia (KPM) telah mengambil inisiatif untuk mengubah senario pendidikan hari ini dengan memperkenalkan pelbagai pendekatan pembelajaran terkini. Pada masa ini, terdapat permintaan dan minat yang tinggi serta kecenderungan di kalangan pelajar dan guru ke arah Pendidikan Sains, Teknologi, Kejuruteraan dan Matematik (STEM). KPM yakin pendekatan pendidikan STEM mampu mengasah kemahiran pemikiran berfikir terutamanya kemahiran berfikir kritis di kalangan pelajar untuk melahirkan pelajar yang bukan sahaja berupaya menjadi pemikir penyelesai masalah yang baik malah, meningkatkan kebolehpasaran sumber tenaga pelajar Malaysia yang berkemahiran dalam bidang STEM. Fokus kajian yang lebih serius harus diberikan untuk melihat secara lebih mendalam bagaimana kaedah pembelajaran STEM menyokong penguasaan kemahiran berfikir khususnya elemen kemahiran berfikir kritis dalam kalangan pelajar sekolah menengah demi memastikan transformasi pendidikan berjaya dilakukan bermula dari pengajaran dan pembelajaran yang berkesan.

\section{Tinjauan Literatur}

\section{Pembelajaran STEM}

STEM merujuk kepada singkatan daripada Sains, teknologi, Kejuruteraan, dan matematik menjadi fokus antarabangsa di bidang kerjaya dan pendidikan untuk menyediakan tenaga kerja berkemahiran dalam bidang STEM. Penekanan terhadap kaedah pembelajaran STEM bertujuan untuk membina sumber manusia yang berupaya untuk melakukan pertimbangan yang baik melalui pemikiran yang kritis, logik dan sistematik supaya pelajar bukan sahaja bersedia menghadapi persaingan global malah, mampu meningkatkan ekonomi negara (Asmuniv, 2015).

Pembelajaran STEM melibatkan pelajar dalam aktiviti "hand-on" dan "mind-on". Pelaksanaan pembelajaran STEM di dalam bilik darjah memberi peluang kepada pelajar untuk memahami kepentingan integrasi pelbagai disiplin dan aplikasi. Pelajar boleh meningkatkan pemikiran logik pelajar melalui integrasi ini (Anwari et Al., 2015).

Menurut kajian Kennedy dan Odell (2014) dan Kelley dan Knowles (2016), pembelajaran STEM yang berkualiti tinggi perlu mempunyai elemen (a) sekurang-kurangnya mengintegrasikan teknologi dan kejuruteraan ke dalam kurikulum sains dan matematik (b) menggalakkan siasatan saintifik dan reka bentuk kejuruteraan, termasuk pengajaran matematik dan sains yang sistematik; (c) pendekatan kolaboratif, menghubungkan pelajar dan guru dengan medan STEM dan secara formal; (d) menyediakan pandangan bersifat global dalam pelbagai perspektif; (e) menggabungkan strategi seperti pembelajaran berasaskan masalah, atau projek dengan menyediakan pengalaman pembelajaran yang formal atau tidak formal; (f) menggabungkan teknologi yang sesuai untuk meningkatkan pembelajaran.

\section{Kemahiran Berfikir Kritis}

Terdapat pelbagai definisi kemahiran berfikir kritis daripada kajian lampau, paling kerap ianya dirujuk sebagai disiplin dan pemikiran kendiri (Halpern, 1998; Paul \& Elder, 2006). Facione (1990) mentakrifkan kemahiran berfikir kritis sebagai "bertujuan, penghakiman berdasarkan peraturan kendiri yang berdasarkan interpretasi, analisis, evaluasi dan inferen juga penjelasan yang berlandaskan bukti, konseptual, metodologi atau mempertimbangkan kontekstual sebelum melakukan penghakiman".

Pemikiran kritikal sering dikaitkan dengan penaakulan, penyelesaian masalah dan membuat keputusan (Willingham, 2008). Kek dan Huijer (2011) menyatakan seseorang yang berfikiran kritikal mempunyai kebolehan untuk menyelesaikan masalah, menganalisis maklumat dengan berkesan dan memiliki kemahiran berfikir tahap tinggi. Pemikiran kritikal boleh di pelajari, tetapi ianya memerlukan persekitaran pembelajaran yang berpusatkan perkembangan kemahiran sebagai objektif pembelajaran (Biggs, 1999). 
Di samping itu, pemikiran kritikal adalah kemahiran yang boleh dipindahkan kepada domain dan disiplin yang lain (Halpern, 1998). Oleh itu, ianya ideal jika kemahiran pemikiran kritikal di ajar di dalam situasi integrasi dan bukan sebagai topik persendirian atau topik tambahan (Kek \& Heuijer, 2011). Untuk memupuk pemikiran kritikal, bilik darjah harus di modifikasi daripada persekitaran berpusatkan guru kepada persekitaran berpusatkan pelajar dan berpusatkan pemikiran kritikal (Jones, Dana, LaFramenta, Adams \& Arnold, 2016). Persekitaran di mana pelajar boleh belajar dengan secara kendiri, menyelesaikan masalah, berkolaborasi terhadap kajian dan menerokai kandungan dunia sebenar. Kemahiran pemikiran kritikal sangat diperlukan untuk berjaya di dalam abad ke 21 .

Graduan STEM yang ingin ikut serta di dalam tenaga kerja, bukan sahaja memerlukan pengetahuan yang mendalam mengenai disiplin STEM, tetapi harus juga mampu untuk menghadapi amalan saintifik, mempunyai kebolehan untuk berfikir secara kritikal dan juga bersikap inovatif (Mulnix \& Vandergrift, 2014). Integrasi aktiviti STEM di sekolah akan memupuk interaksi sosial dan penerokaan, yang boleh membantu dalam mengembangkan pemikiran kritis murid, komunikasi, dan kemahiran penyelesaian masalah (DeJarnette, 2012). Dalam persekitaran PdP di Malaysia, KPM telah menyediakan Model kemahiran Berfikir dan Strategi Berfikir (KBSB) yang mengandungi dua bahagian penting iaitu, kemahiran berfikir kreatif and kemahiran berfikir kritis yang telah diterapkan dalam semua Kurikulum Standard Sekolah Menengah (KSSM) di Malaysia. Kedua-dua bahagian ini diaplikasikan setiap kali pelajar menggunakan konsep strategi berfikir untuk menyelesaikan masalah. Rajah 1 menunjukkan Model kemahiran Berfikir dan Strategi Berfikir (KBSB) KPM.

\section{Rajah 1: Model kemahiran Berfikir dan Strategi Berfikir KPM}

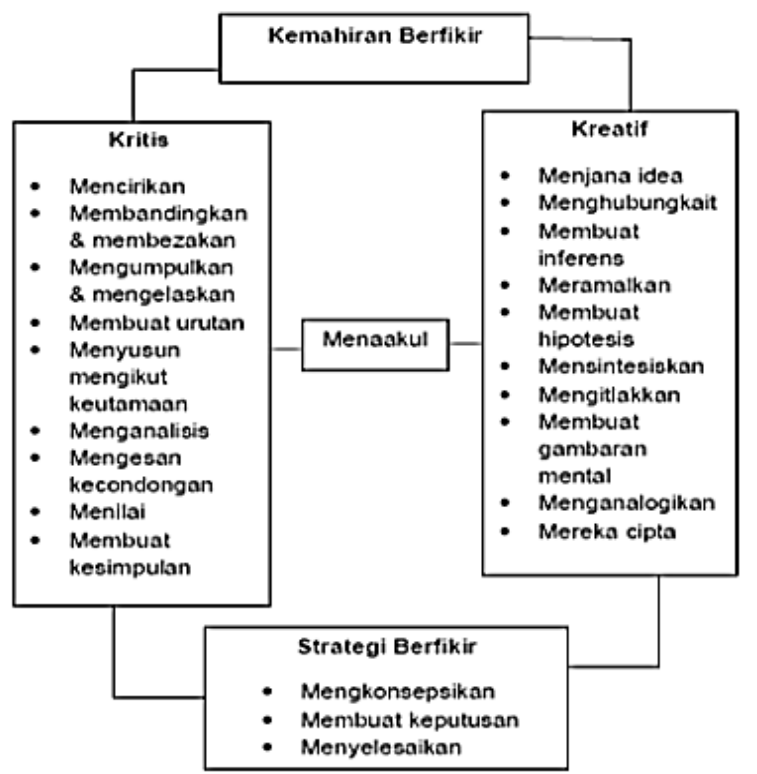

(Sumber: Dokumen Standard Kurikulum dan Pentaksiran Sains Tingkatan 2)

Dalam kajian ini, pengkaji memilih untuk mengadaptasi model Kemahiran Berfikir dan Strategi Berfikir KPM kepada asas model kemahiran berfikir kajian ini. Menurut Maria Salih dan Nurulhuda Abd Rahman (2013), model yang diperkenalkan oleh KPM bersifat holistik dan sifat holistik ini diperlukan oleh pelajar apabila menyelesaikan masalah apabila kemahiran di tahap yang lazim. Walau bagaimana pun, kajian ini akan cuba memfokuskan ciri elemen kemahiran berfikir kritis tang bertindih dengan elemen KBAT iaitu; Menganalisis, Menilai dan Mereka Cipta yang di mana, elemen menganalisis merujuk kepada keupayaan pelajar untuk melakukan pencerakinan maklumat kepada bahagian kecil untuk memahami dengan lebih mendalam berkenaan serta hubung kait antara bahagian. Seterusnya melihat kepada elemen menilai melibatkan usaha pelajar membuat pertimbangan dan keputusan menggunakan pengetahuan, pengalaman, kemahiran, dan nilai serta memberi justifikasi. Elemen mereka cipta penyelesaian masalah pula memerlukan pelajar untuk berupaya membuat 
pernyataan tentang hasil sesuatu kajian yang berdasarkan kepada sesuatu pembuktian dan cuba jaya. Model ini juga memudahkan pengkaji menyelaraskan latihan pelajar mengikut Dokumen Standard Kurikulum Pentaksiran (DSKP) Sains untuk pelajar tingkatan 2.

Jadual 1.1: Panduan Rubrik Aras sasaran elemen menganalisis, menilai dan mereka cipta dalam KBAT

\begin{tabular}{ll}
\hline \multicolumn{1}{c}{$\begin{array}{c}\text { Elemen Kemahiran Berfikir Kritis dan } \\
\text { Definisi }\end{array}$} & $\begin{array}{c}\text { Disposisi Elemen Kemahiran Berfikir } \\
\text { Kritis }\end{array}$ \\
\hline $\begin{array}{l}\text { Menganalisis } \\
\text { (Mengasingkan maklumat kepada komponen }-\end{array}$ & $\begin{array}{l}\text { Mencerakinkan, memilih, mencirikan, } \\
\text { komponennya untuk memahami dan }\end{array}$ \\
membuat perhubungan antara komponen) & $\begin{array}{l}\text { membuat andaian, menyelesaikan masalah, } \\
\text { membuat urutan, membuat kesimpulan, }\end{array}$ \\
& $\begin{array}{l}\text { mengawal pemboleh ubah, menggunakan } \\
\text { perhubungan ruang dan masa, menyusun }\end{array}$ \\
& mengikut keutamaan, menjelaskan melalui \\
& contoh, membuat kajian, menterjemahkan, \\
& mengeksperimen, menghitung
\end{tabular}

\section{Menilai}

(Mewajarkan keputusan atau tindakan yang telah diambil atau pun menilai idea/bahan/ maklumat/ kaedah berdasarkan kriteria yang spesifik)

\section{Mereka cipta}

(Menggabungkan idea/komponen dengan menggunakan pemikiran yang kreatif untuk menghasilkan idea/struktur baharu)
Mentaksir, mengkritik, mentafsir, menyokong, merumuskan, mempertahankan, mewajarkan menguji, mengesan kecondongan, membuat keputusan, membahas

Menggabungkan, merancang, meringkaskan, membina, merangkakan, mereka bentuk, mencipta, mengkonsepsikan, menganalogikan, membuat gambaran mental, berkomunikasi, mengeksperimen, membuat hipotesis, mendefinisikan secara operasi, menambah baik, menulis

Sumber: Dokumen Standard Kurikulum dan Pentaksiran Sains Tingkatan 2.

\section{Metod Kajian}

Penyelidikan kualitatif melalui kaedah kajian kes telah dipilih sebagai metod kajian ini. Kes yang dirujuk adalah pembelajaran penyebatian yang disarankan oleh (Lin, 2014) berdasarkan penyelidikan Swartz dan Parks (1994). Kajian kes ini melibatkan proses pemikiran aktif dalam pembelajaran dan memberi tumpuan kepada penyelesaian masalah melalui perbincangan kumpulan untuk mengaktifkan pemikiran dan pembelajaran murid.

Kajian ini mengadaptasi kaedah kualitatif kerana ianya adalah metod yang efektif untuk penyelidikan di dalam bidang pendidikan (Chow, 2005). Terutama sekali untuk kajian yang ingin memahami dan mengintepretasi fenomena sosial yang kompleks dari sudut pandangan peserta untuk dibandingkan dengan paradigma saintifik. Manakala pendekatan kajian kes digunakan kerana ianya mempunyai keupayaan untuk menerokai dan mendalami objektif kajian, iaitu elemen kemahiran berfikir kritis dominan sepanjang program latihan robot STEMINO yang berasaskan penyelesaian masalah.

Instrumen penyelidikan kualitatif seperti temu bual, pemerhatian, analisis perbincangan pembentangan dan nota lapangan guru telah dilaksanakan untuk mengumpul data daripada peserta. Pengkaji akan melakukan pemerhatian di setiap fasa program latihan robot STEMINO dan temu bual akan dilakukan 
pada penghujung fasa. Analisis dokumen merangkumi hasil perbincangan setiap kumpulan dan juga nota lapangan yang dicatat oleh guru.

Data yang diperoleh dari pemerhatian digunakan sebagai landasan untuk mengenal pasti elemen kemahiran berfikir kritis. Manakala temu bual dengan peserta dan guru akan mengesahkan data dari pemerhatian dan juga memberikan maklumat tambahan yang tidak diliputi oleh pemerhatian. Seterusnya, analisis dokumen perbincangan pembentangan dan nota lapangan guru dilakukan untuk menyokong dapatan dari temu bual dan pemerhatian.

Populasi kajian ini adalah 24 pelajar tingkatan 2 dan guru di sekolah menengah daerah Tuaran, Sabah. Persampelan telah dilakukan untuk memilih sekumpulan peserta yang bersesuaian dengan keperluan kajian dari aspek batas masa dan kos perbelanjaan. Di samping itu, seramai 4 guru telah dipilih untuk menyertai kajian ini sebagai pembantu kepada pengkaji untuk melancarkan proses pemerhatian, temu bual dan analisis dokumen.

Dapatan temu bual, pemerhatian dan analisis dokumen akan di analisis secara triangulasi untuk memastikan data kualitatif mempunyai kebolehpercayaan yang tinggi. Data di analisis secara triangulasi berdasarkan objektif kajian iaitu mendalami elemen kemahiran berfikir kritis sepanjang pembelajaran STEM berasaskan robot di luar waktu sekolah.

\section{Dapatan Kajian}

Kajian kes ini disertai oleh 24 orang peserta yang dibahagikan kepada 6 kumpulan (4 peserta untuk satu kumpulan) dan juga 4 guru. Kriteria peserta adalah pelajar tingkatan 2 atau guru sekolah menengah di daerah Tuaran, Sabah. Untuk memenuhi ciri kerahsiaan, kesemua peserta dan guru yang terlibat akan diberikan label tersendiri. Semua peserta dipilih melalui proses persampelan dan bersetuju untuk menyertai kajian dengan suka rela. Lokasi kajian adalah di sebuah sekolah menengah di daerah Tuaran, Sabah dan kajian di lakukan di luar waktu persekolahan.

Peserta dan guru mengikuti Pembelajaran STEM Berasaskan Robot yang terbahagi kepada tiga fasa; (1) pengenalan mengenai kemahiran yang diperlukan dan elemen kemahiran berfikir kritis, (2) pemasangan dan pengaturcaraan robot dan (3) pertandingan robot. Proses pemerhatian, temu bual dan analisis dokumen dilakukan oleh pengkaji sepanjang sesi pembelajaran.

Data temu bual dan pemerhatian yang diperoleh diproses berdasarkan kaedah analisis kandungan yang terbahagi kepada tiga prosedur: (1) penyaringan data, (2) membuat kesimpulan dan semakan, (3) pembentukan kategori dan tema. Selain itu, analisis dokumen berdasarkan hasil perbincangan setiap kumpulan dan nota catatan guru akan dijadikan kayu pengukur untuk menentukan disposisi elemen, yang dominan dan hierarki disposisi elemen.

\section{Kemahiran Berfikir Kritis Sepanjang Fasa 1, Fasa 2 dan Fasa 3}

Data deskriptif yang diperoleh daripada pemerhatian dan temu bual telah disaring dan kemudian di kategorikan. Hasil pengkategorian menunjukkan terdapat tiga tema elemen kemahiran berfikir kritis bersama disposisi elemen yang paling dominan dan kerap ditampilkan oleh para peserta. Ringkasan dapatkan kajian disenaraikan dalam Jadual 2. Semakan lanjut terhadap elemen menganalisis, menilai dan mereka cipta melalui analisis dokumen telah mendapati bahawa wujudnya disposisi dominan elemen kemahiran berfikir kritis yang ditunjukkan oleh peserta seperti ditunjukkan dalam Jadual 1. Oleh yang demikian, dapatan kajian telah menemui sebanyak 5 elemen kemahiran berfikir kritis sepanjang pembelajaran STEM berasaskan Robot (Outside of School Time) di luar waktu sekolah menengah ini. 
Malaysian Journal of Social Sciences and Humanities (MJSSH), Volume 5, Issue 7, (page 32 - 50), 2020

DOI: https://doi.org/10.47405/mjssh.v5i7.444

Jadual 2: Elemen Dominan Kemahiran Berfikir Kritis Sepanjang Fasa 1,2,3

\begin{tabular}{cl}
\hline Elemen & \multicolumn{1}{c}{ Disposisi Dominan } \\
\hline Menganalisis & Menggunakan Perhubungan Ruang Dan Masa \\
& Mencirikan \\
& Membuat Kesimpulan \\
Menilai & Membuat Keputusan \\
& Mempertahankan \\
& Mewajarkan Keputusan \\
Mereka Cipta & Berkomunikasi \\
& Mengkonsepsikan
\end{tabular}

\section{Disposisi Dominan Elemen Menganalisis}

\section{Menggunakan Perhubungan Ruang dan Masa}

Pelajar Nadia menyatakan dalam temu bual telah melakukan proses pemilihan hasil analisis nilai matematik dan saintifik yang melibatkan aplikasi perhubungan ruang dan masa. Pelajar Nadia memaksimumkan manipulasi perhubungan ruang dan masa daripada data matematik dan saintifik yang diterjemahkan oleh kekangan pergerakan robot di atas permukaan karpet yang kasar untuk menghasilkan pergerakan terpantas oleh robot. Pelajar Jasman juga mengubah dan menyesuaikan nilai putaran tayar robot dengan permukaan kawasan pergerakan robot secara di lapangan. Kedua-dua pelajar telah manipulasi perhubungan ruang dan masa untuk menganalisis kelancaran pergerakan robot masing-masing.

"Kawasan karpet memang lambat, robot pandai sekat-sekat. Kami susun balik laluan dengan kelajuan. Pilih-pilih mahu tukar jalan atau rugi masa." TB05/P/F3KBK/ANA/NADIA/P01/B231

“...daya geseran tinggi so, lambat robot... Putaran tayar robot perlu kasi laju atau kasi tukar laluan lain...mahu pandai cari kawasan yang robot boleh bergerak dengan bagus." TB05/P/F3KBK/ANA/JASMAN/P06/B338

Daripada sudut pandangan yang berbeza, hasil temu bual dengan guru Amie dan guru Alice setuju dengan menyatakan bahawa untuk menetapkan laluan terpantas untuk robot, pelajar Nadia dan Jasman menyelaraskan pemerhatian hubungan ruang dan masa dengan hasil terjemahan data matematik dan saintifik semasa lapangan.

"Pelajar tentukan laluan yang paling menjimatkan bateri dan pantas dengan melihat daripada jarak, kuasa bateri dan masa. Pelajar menyusun mencari laluan yang terbaik mengikut syarat." TB06/G/F2KBK/ANA/AMIE/G01/B127

"Kebolehan untuk mengira kerja, menjangkakan masa dan jarak pergerakan robot membantu pelajar mencadangkan laluan yang terbaik untuk misi mereka." TB06/G/F2KBK/ANA/ALICE/G02/B131

Di samping itu, pelajar Hawa menyatakan pertimbangan hubungan ruang dan masa bukan sahaja boleh dikira secara matematik tetapi juga boleh diperoleh melalui pemerhatian keadaan pergerakan robot di lapangan, contohnya keadaan dan pergerakan robot di permukaan yang berlainan akan menghasilkan kelajuan pergerakan robot yang berlainan.

"Tengok keadaan robot gerak, boleh tahu mana yang daya geseran paling besar kalau kelajuan paling rendah lah, cikgu. Kalau jalan licin, kasi perlahan sebab 
Malaysian Journal of Social Sciences and Humanities (MJSSH), Volume 5, Issue 7, (page 32 - 50), 2020

DOI: https://doi.org/10.47405/mjssh.v5i7.444
kadang-kadang
robot
laju
pandai
terbabas."
TB05/P/F3KBK/ANA/HAWA/P04/B211

"Nampak tu bila kelajuan tempat laluan yang berbeza...kena kasi adjust supaya robot boleh gerak dengan bagus di semua laluan sampai keluar, cikgu." TB05/P/F3KBK/ANA/NADIA/P01/B238

Guru Hamie menambah, pelajar Hawa bukan sahaja berpeluang mendapat latihan teknikal tetapi juga bersama-sama rakan yang lain berlatih untuk mendapatkan data melalui deria yang lain, melalui pemerhatian, menyusun logik sesuatu proses pembelajaran mengikut kronologi secara praktikal . Guru Jose turut menyatakan pelajar Jasman menunjukkan kefahaman apabila boleh mengendali senario yang rumit secara pemahaman teori malah dipraktikkan oleh pelajar Jasman di lapangan masa ketika itu.

"Pelajar praktik kemahiran teknikal dengan logik untuk mengatasi masalah yang berlaku di lapangan terutamanya menyesuaikan kekangan pergerakan untuk cari laluan terpantas untuk siapkan misi." TB06/G/F2KBK/ANA/HAMIE/G03/B138

"Masalah teknikal yang melibatkan pertimbangkan antara ruang dan masa robot melatih mereka untuk memahami senario rumit ke penyelesaian yang bermakna." TB06/G/F2KBK/ANA/JOSE/G4/B 146

\section{Mencirikan}

Pelajar Aliah menyatakan telah timbul kekeliruan terhadap isi kandungan yang mana satu lebih relevan akibat lambakan maklumat yang terkumpul. Namun, maklumat ini secara beransur-ansur dicirikan mengikut ciri-ciri idea dengan menjawab keperluan pelaporan operasi misi. Pelajar Hawa pula menggunakan semua data matematik, saintifik, data pemerhatian dan maklumat mentah daripada internet untuk memahami situasi kebakaran yang berlaku. Ekoran ini, pelajar Aliah dan pelajar Hawa mendapati bahawa dengan mencirikan maklumat yang diperoleh, kefahaman mereka lebih jelas, di mana perkaitan dan kesinambungan maklumat mendorong pelajar untuk menyiapkan pelaporan operasi misi secara lebih tersusun.

"Susah mahu faham kalau terlampau banyak. Kalau dikasi asing-asing senang mahu faham. Senang mahu gabung maklumat untuk bina draf pembentangan misi mencari dan menyelamat." TB05/P/F3KBK/ANA/ALIAH/P02/B251

"First, kena pilih maklumat yang berkaitan saja. Second, kasi pilih dan masukkan dalam label yang betul. Susun satu-satu baru boleh bina ayat untuk atur misi ini, cikgu." TB05/P/F3KBK/ANA/HAWA/P04/B263

Guru Hamie juga berpendapat bahawa latihan fasa 3 memberi banyak peluang untuk pelajar menguasai elemen memilih dan mencirikan maklumat secara lebih berfokus dengan penekanan terhadap kefahaman yang tepat. Selain itu, Amie turut bersetuju bahawa perbincangan dalam kumpulan yang dilakukan turut digunakan untuk memastikan kefahaman itu betul berdasarkan objektif tugasan sepanjang sesi latihan fasa 3 .

"Paling banyak proses analisis di sesi ini kerana saya rasa mereka sudah tahu apa mahu dibuat ikut pengalaman latihan yang sebelum ini untuk menjawab tugasan ini. Pelajar mengasingkan dan memilih maklumat yang relevan saja." TB06/G/F2KBK/ANA/HAMIE/G03/B154

"Mereka Learning by doing sendirian atau dalam kumpulan. Ini termasuk mencirikan terma sains daya, kuasa dan kerja oleh robot semasa praktikal untuk mengumpul data dengan tepat." TB06/G/F2KBK/ANA/AMIE/G01/B163 
DOI: https://doi.org/10.47405/mjssh.v5i7.444

Pelajar Nadiah dan pelajar Banny turut telah menyatakan bahawa ciri-ciri yang spesifik mengikut sesuatu isi kandungan bukan sahaja membantunya mengurus maklumat dengan lebih baik malah, merangsang kefahaman isi kandungan dan janaan idea untuk pelaporan misi.

"Kalau dikasi pecah ikut jenis maklumat senang mahu urus dapatkan data...Kami pilih masukkan data yang bagus saja. Kalau tidak happy, kami ulang ambil data. Nanti kami kasi faham sama-sama masa perbincangan untuk idea." TB05/P/F3KBK/ANA/NADIA/P01/B231

"Bila kami tau apa yang mahu dicari tu senang untuk faham dan bentang apa kita mahu bentang...kami bincang dan kasi tetap apa yang mahu dicari untuk masukkan ke dalam label maklumat." TB05/P/F3KBK/ANA/BANNY/P03/B236

Penyataan guru Alice turut disokong oleh guru Jose yang turut bersetuju dengan kenyataan pelajar bahawa dengan mengasingkan maklumat mengikut ciri penyataan matematik dan kenyataan saintifik telah membantu menjelaskan idea dan cadangan pelajar dengan lebih baik.

"Huraian istilah sains dan terma matematik dapat dibuat dengan baik bila pelajar boleh faham dan boleh menjelaskan istilah dan terma itu yang baik melalui tulisan, kiraan atau pun cuba menjelaskannya semula. Saya lihat pelajar memilih hanya data yang cantik dan logik saja untuk direkodkan sebagai data tugasan." TB06/G/F2KBK/ANA/ ALICE/G02/B13

"Mereka buat kategori maklumat yang mereka perlu cari untuk membina bahan untuk tugasan. Semua data dan maklumat dimasukkan dalam satu kumpulan label yang sama untuk membina isi kandungan pembentangan."

TB06/G/F2KBK/ANA/JOSE/G04/B19

Seperkara yang menarik dinyatakan oleh pelajar ialah, melalui proses pengasingan dan mencirikan maklumat membantu perbincangan pelajar untuk lebih fokus kepada ciri-ciri robot untuk situasi kebakaran yang berlaku, contohnya, keperluan robot mempunyai fungsi yang lebih spesifik seperti berkulit kalis api dan haba untuk merempuh unggunan api yang marak.

"Lepas berbincang lepas kasi asing maklumat, baru kami faham rupanya kami kena kasi lain robot yang mencari dan robot yang menyelamat. Robot ini tidak sama, cikgu. Lain-lain bentuk dia. Fungsi pun memang lain-lain”

TB05/P/F3KBK/ANA/ HAWA/P04/B21

"Kami fikir lagi apa yang boleh kami kasi tambah untuk buat robot kami sesuai ikut apa ciri yang dikasi senarai. Untuk kebakaran lain, untuk selamatkan orang lain ...mengakali (mungkin) boleh digabungkan tu fungsi.",

TB05/P/F3KBK/ANA/ FATIN/P05/B32

Guru Amie juga menyaksikan bahawa pelajar- pelajar mula lebih kritis dan kreatif dalam perbincangan kumpulan apabila mula menganalisis ciri-ciri alternatif serta fungsi robot yang diperlukan berdasarkan situasi. Guru Alice melihat ekstrapolasi ciri-ciri reka bentuk yang dicadangkan disokong oleh fakta terkumpul, rujukan guru pakar dan justifikasi secara konsensus dalam kumpulan.

“...pelajar menganalisis ciri-ciri robot yang sesuai dengan keadaan situasi kebakaran. Ciri-ciri robot dibincangkan dipilih selepas diasingkan ikut apa justifikasi dan pendapat guru pakar." TB06/G/F2KBK/ANA/AMIE/G01/B12

"Pelajar guna ciri-ciri yang terpilih...pelajar membuat justifikasi yang munasabah untuk memilih reka bentuk robot mengikut ciri-ciri robot yang mereka rasa paling sesuai untuk misi mereka." TB06/G/F2KBK/ANA/ ALICE/G02/B17 
Malaysian Journal of Social Sciences and Humanities (MJSSH), Volume 5, Issue 7, (page 32 - 50), 2020

\section{Membuat Kesimpulan}

Pelajar Jasman menyatakan dalam temu bual, cadangan pergerakan robot untuk menyelesaikan misi ini berdasarkan kesimpulan kecil daripada setiap gerak langkah penyelesaian masalah yang diperlukan dalam tugasan ini. Pada akhir proses, pelajar Banny percaya penetapan cadangan terakhir telah dibuat dalam perbincangan kumpulan berdasarkan kesimpulan-kesimpulan kecil yang telah dibuat pada peringkat lebih awal.

"Gerak kerja yang last, paling banyak yang kena dibuat sama fikir untuk buat keputusan. Kena atur mana laluan paling bagus, siapa yang bergerak masuk duluan... Setiap step mesti kena fikir, tengok pada keadaan dan fakta. Kumpulan kami buat rumusan untuk setiap langkah soalan tugasan cikgu." TB05/P/F3KBK/ANA/JASMAN/P06/B341

"Kasi cadang dulu ikut apa yang kita dapat, baru kena bincang lagi. Macam...sebab orang tua tu buta dan sakit nah kan, atau budak perempuan masih selamat dalam bilik kecil tu diselamatkan duluan. Kasi tetap perbincangan bahagian A baru kasi gabung dengan keputusan di bahagian B". TB05/P/F3KBK/ANA/BANNY/P03/B357

Melalui temu bual, guru Hamie dan guru Jose menyatakan bahawa penghasilan kesimpulan yang berasaskan terjemahan data matematik dan fakta saintifik yang tepat oleh pelajar menggalakkan penyusunan idea penyelesaian masalah tugasan dilakukan dengan lebih sistematik.

"Kesimpulan dibuat dalam kumpulan berdasarkan fakta dan maklumat sains dan
matematik yang betul di peringkat awal. Pertimbangan untuk memutuskan mana
yang lebih penting contohnya, menyelamatkan siapa dahulu adalah berdasarkan
kiraan matematik dan kefahaman situasi berdasarkan fakta sains yang
dibincangkan dalam kumpulan." TB06/G/F2KBK/ANA/HAMIE/G03/B86

"Rumusan dan kefahaman sains dan matematik yang tepat dengan keadaan kebakaran masa ketika itu membantu pelajar membuat urutan penyelamatan yang lebih baik." TB06/G/F2KBK/ANA/JOSE/G04/B94

Bukan setakat itu sahaja, pelajar Fatin menyediakan kesimpulan terhadap penyelesaian masalah teknikal sebagai panduan untuk masalah yang dihadapi dalam fasa 3. Pelajar Hawa turut menyatakan bahawa kesimpulan terhadap penyelesaian masalah teknikal di peringkat ini ditambah baik melalui proses pemeriksaan dan pemantauan berulang terhadap pemasangan, urutan pengekodan dan komunikasi teknikal robot.

"Kami rasa perlu untuk buat satu rumusan cara repair untuk robot kami jaga kelajuan robot. Kami check dan ulang balik check problem robot macam gerak kerja yang lepas" TB05/P/F3KBK/ANA/ FATIN/P05/B311

"Tapi pada masa ini, saya boleh sudah agak apa masalah robot dengan lihat apa penyakit robot sudah (ketawa)... ini rumusan sema ikut pengalaman fasa 1 sama 2...robot kadang-kadang tidak mahu gerak ikut arahan, tapi kalau tengok cara gerak boleh tahu sudah apa masalah." TB05/P/F3KBK/ANA/HAWA/P04/B377

Menurut guru, pelajar seperti Fatin dan Hawa mulai peka terhadap kelemahan dan kesilapan dalam proses penyediaan robot untuk mencari penyelesaian masalah teknikal sepanjang fasa program berlaku. Guru menyokong penyataan pelajar bahawa kesimpulan terhadap punca dan penyelesaian masalah teknikal adalah berdasarkan pengalaman penyelesaian teknikal semasa fasa 1 dan 2 . Kesimpulan ini dijadikan panduan semasa fasa 3 . 
Malaysian Journal of Social Sciences and Humanities (MJSSH), Volume 5, Issue 7, (page 32 - 50), 2020

DOI: https://doi.org/10.47405/mjssh.v5i7.444

"Masa menulis laporan final, pelajar guna semua pengalaman dari fasa 1 hingga 3 untuk buat kesimpulan terhadap masalah teknikal yang berulang-ulang" TB06/G/F2KBK/ANA/ALICE/G02/B114

"Pelajar sangat fokus terhadap masalah teknikal...apa yang mereka simpulkan dalam fasa lepas digunakan dalam fasa 3 di lapangan dan dalam laporan..." TB06/G/F2KBK/ANA/ HAMIE/G03/B124

\section{Kemahiran Menilai}

\section{Membuat Keputusan}

Pelajar Fatin menyatakan bahawa pelajar dalam kumpulan membuat penilaian ke atas beberapa alternatif pilihan laluan yang ada secara berulang kali berdasarkan pengalaman teknikal dan fakta sains serta matematik yang dikumpul sepanjang fasa sebagai panduan dan juga membuat keputusan. Pelajar Nadia melakukan penyesuaian untuk mendapat keputusan masa terbaik. Penilaian yang berulang akhirnya membuahkan suatu dapatan yang konsisten dan akhirnya, diyakini sebagai keputusan terbaik.

"Memang banyak pilihan laluan tapi kami pilih laluan yang bacaan yang paling bagus, kami check dengan panduan sama kawan-kawan lain juga untuk nilai pergerakan mana yang paling bagus, cikgu."

TB05/P/F3KBK/NILAI/ FATIN/P05/B381

"Kami cuba cari maklumat sampai balik-balik kami dapat nilai yang sama dan sampai yakin ikut laluan ini memang tiada sudah masalah yang lain ...keputusan dibuat dalam kumpulan juga, cikgu...” TB05/P/F3KBK/NILAI/ NADIA/P01/B386

Melalui temu bual guru, guru Hamie menjelaskan bahawa pelajar giat mencuba untuk membuktikan prestasi strategi setiap laluan robot sebelum keputusan dibuat. Guru Amie mengatakan ada kalanya pelajar kecewa ketika cubaan gagal mencapai sasaran atau dikekang oleh masalah teknikal. Walau bagaimana pun, pelajar tetap berusaha untuk mengulang uji selia di lapangan sehingga dapatan yang terbaik ditemui sebelum pelajar menamatkan uji selia di lapangan dan berbincang untuk membuat keputusan terbaik.

"Keputusan dibuat selepas berbincang, selepas uji apa andaian, pilihan laluan dan jika pelajar rasa itu adalah reka bentuk robot yang terbaik."

TB06/G/F3KBK/NILAI/ HAMIE/G03/B83

"Mereka membuat ulangan cubaan terhadap penggunaan rumus, nilai program dan segala. Penilaian dilakukan di lapangan banyak kali sampai kumpulan puas hati sebelum keputusan atas pilihan laluan muktamad dibuat dalam kumpulan." TB06/G/F3KBK/NILAI/ AMIE/G01/B95

Pelajar Nadia menambah lagi bahawa semasa akhir fasa, pelajar menyatakan bahawa lebih selesa untuk melakukan pemilihan ke atas laluan alternatif yang ada secara konsensus yang melibatkan semua ahli mengikut peranan masing-masing. Semua pilihan laluan dipertimbangkan dengan data dan hujah dibentangkan oleh ahlinya sehingga persetujuan bersama dicapai. Bagi pelajar Aliah pula, dalam kumpulan persetujuan bersama adalah sangat penting dalam pemilihan akhir strategi misi mencari dan menyelamat kebakaran.

"Kami bincang dalam kumpulan, cikgu. Boleh bincang pilih mana yang bagus terus pilih laluan yang paling bagus juga. Boleh tanya soalan sama kawan-kawan, boleh terus explain apa sebab dia pilih laluan sama fungsi begitu untuk robot." TB05/P/F3KBK/NILAI/ NADIA/P01/B371 
"Paling bagus kalau semua pun setuju dengan pelan itu sama-sama, cikgu. Senang atur nanti. Bila puas hati nanti semua pun kerjasama atur strategi misi." TB05/P/F3KBK/NILAI/ ALIAH/P02/B396

Menurut guru Alice, perbincangan kumpulan yang dibuat bertujuan untuk mendapatkan persetujuan bersama membuat keputusan. Kekuatan dan keyakinan pelajar dalam proses ini dilihat adalah daripada kerjasama dan konsensus keputusan memilih alternatif pilihan. Guru Hamie menambah bahawa pelajar membina dan memilih alternatif pilihan daripada pilihan yang dipersetujui oleh semua ahli yang berlainan dalam peranan misi. Ketua dilihat sebagai moderator untuk menjalinkan semua idea dan idea operasi dan strategi sehingga semua ahli berpuas hati dan bersetuju untuk mengangkat satu laluan terbaik yang memenuhi syarat laluan terpantas.

"Dari pada hasil perbincangan, pelajar bersetuju secara satu kumpulan. Dan memilih untuk memilih alternatif laluan dan strategi misi setelah semua orang berpuas hati membincangkan cadangan masing-masing." TB06/G/F3KBK/NILAI/ ALICE/G02/B154

"Mereka boleh main peranan seperti tugasan peranan yang diberi. Mereka memahami situasi dan apa yang mereka sepatutnya lakukan sebagai ahli misi mencari dan menyelamat. Mereka sedar kekuatan pelan dan keyakinan kumpulan untuk berjaya dalam misi itu adalah berdasarkan keputusan bersama." TB06/G/F3KBK/NILAI/ HAMIE/G03/B161

\section{Mempertahankan Pilihan}

Dalam temu bual, pelajar Banny menyatakan perlu mempertahankan alternatif pilihan dengan melakukan uji selia robot di lapangan. manakala, pelajar Fatin menggunakan maklumat dan data lapangan sebagai rujukan untuk mempertahankan laluan robot yang dipilih. Contohnya dengan menggunakan kira-kira matematik berkaitan aspek ketahanan bateri dan kelajuan yang telah dicatatkan semasa uji selia di lapangan untuk menyokong kembali alternatif pilihan.

"Ada sesi untuk kritik, tapi kami juga sediakan hujah untuk pertahankan pendapat dari segi data dan guna maklumat yang tepat...Saya rasa lebih bagus lagi kalau sudah buat ujian di lapangan." TB05/P/F3KBK/NILAI/ BANNY/P03/B511

"Kami pastikan bateri cukup untuk sepanjang misi. charge penuh dan masa dengan kelajuan ujian. kami uji dengan robot pergerakan untuk demo kasi jelas pergerakan mencari dan menyelamat tu, cikgu." TB05/P/F3KBK/NILAI/ FATIN/P05/B532

Menurut temu bual guru Jose dan Alice pula, menceritakan bahawa ahli kumpulan memahirkan diri untuk menangani kritikan yang datang daripada ahli-ahli kumpulan dan juga guru pembimbing mereka ketika itu. Pelajar cenderung menggunakan tiga aspek iaitu rumusan matematik, fakta sains dan dapatan di lapangan untuk memperkukuhkan pilihan alternatif yang dibuat oleh ahli-ahli kumpulan.

"Semasa keputusan dibahaskan, mereka berbahas untuk menentukan siapa yang dahulu diselamatkan dan laluan masa yang paling selamat. Selalu pelajar guna penyataan matematik dan menggunakan situasi kebakaran itu untuk mempertahankan idea masing-masing." TB06/G/F3KBK/NILAI/JOSE/G04/B46

"Mereka guna keputusan di lapangan sebagai bukti laluan ini memang yang terbaik.” TB06/G/F3KBK/NILAI/ ALICE/G02/B49

Pelajar Banny dan pelajar Fatin turut menyatakan bahawa pelajar menangani perselisihan pendapat ini dengan cara memperjelaskan semula justifikasi pemilihan mereka melalui rujukan buku panduan, penyataan kira-kira dan keberkesanan laluan robot semasa uji selia di lapangan. Pada akhir 
perbincangan, pelajar turut melahirkan perasaan puas hati kerana mampu menangani, menerima dan membalas proses kritikan. Selain itu, pelajar juga menyedari bahawa penggunaan rumusan matematik dan fakta sains yang tepat sangat membantu menyokong hujah dan membantu mengukuhkan kekuatan pilihan alternatif yang dibuat melalui perbincangan kumpulan.

"Kalau ada orang tidak setuju dengan idea... kami semak ikut apa di buku panduan, tengok balik kira-kira dan memang boleh bergerak di laluan robot kami. Iya... kami bincang juga flow dalam misi menyelamat."

TB05/P/F3KBK/NILAI/ BANNY/P03/B411

"Ok saja. Debat saja...ada idea - idea yang lagi lebih kreatif dan logik. Kena guna sains dan matematik untuk kasi kuat idea kita. Lepas itu, kena bincang dalam kumpulan supaya semua pun sokong." TB05/P/F3KBK/NILAI/ FATIN/P05/B418

Temu bual guru Hamie menyatakan bahawa pelajar diasak dalam keadaan yang memerlukan mereka bukan sahaja untuk meyakinkan semua ahli kumpulan dalam menyiapkan aspek penugasan misi malah, yang paling penting adalah untuk membuatkan mereka faham dengan perancangan misi yang diketengahkan. Guru Alice turut menyatakan bahawa pelajar menyedari perlu menggunakan maklumat yang sahih untuk menyokong isi kandungan dalam pelaporan misi robot.

"Mereka mempertahankan pelan misi kerana menghayati dan faham kepentingan tugas mereka sebagai ahli penyelamat... mereka lebih serius dalam gerak kerja terutamanya semasa perbincangan untuk memilih laluan misi robot." TB06/G/F3KBK/NILAI/ ALICE/G02/B187

"Pelajar menggunakan maklumat untuk menyokong. Pelajar menjelaskan mana yang paling selamat, paling praktikal untuk digunakan. Dengan berpandukan maklumat, pelajar menilai penyataan matematik, sains dan maklumat daripada lapangan dalam kumpulan untuk diguna mempertahankan isi kandungan pelaporan misi robot pelajar.” TB06/G/F3KBK/NILAI/ HAMIE/G03/B182

\section{Mewajarkan Pilihan Alternatif}

Dapatan temu bual antara pelajar Aliah dan Banny menyatakan lebih memberikan penekanan terhadap hasil uji selia di lapangan untuk mewajarkan pilihan laluan yang dibuat. Menurut pelajar, uji selia bertujuan untuk mengesahkan prestasi terbaik robot dengan cadangan strategi misi yang dirancang. Rangka misi diuji untuk menyokong setiap langkah strategi dan prestasi robot ketika itu. Semakan dan penjajaran semula dilakukan berdasarkan keputusan praktikal robot di lapangan.

"Kami buat tiga kali cubaan bacaan untuk dapat purata bacaan yang lebih bagus...banyak kali sampai kami rasa itu paling bagus." TB05/P/F3KBK/NILAI/ ALIAH/P02/B32

"Kami selalu rujuk semula supaya apa kami buat betul...tengok masalah kebakaran ini kalau sama dengan maklumat dikumpul masa awal-awal kelas. Check balik kadar oksigen dan halangan pergi ke sana... Info yang kami dapat dari tugasan, kami check di internet" TB05/P/F3KBK/NILAI/BANNY/P03/B43

Guru Jose menyokong kenyataan pelajar dengan menyatakan bahawa pelajar melakukan uji selia secara intensif untuk mendapatkan laluan strategi misi yang terbaik. Guru Amie menyaksikan bahawa pelajar bukan sahaja berusaha untuk memperkukuhkan idea perancangan di lapangan malah pelajar sering merujuk guru untuk mendapatkan pengesahan apa yang mereka buat dan dapat adalah tepat.

"Hasil ujian di lapangan mewajarkan keputusan yang kumpulan buat. Buat praktikal di lapangan dengan keputusan ujian nilai yang baik memberikan 
Malaysian Journal of Social Sciences and Humanities (MJSSH), Volume 5, Issue 7, (page 32 - 50), 2020

DOI: https://doi.org/10.47405/mjssh.v5i7.444

justifikasi dan keyakinan untuk mereka laporkan isi kandungan misi robot pelajar." TB06/G/F3KBK/NILAI/JOSE/G04/B76

“...pelajar membuat tafsiran di lapangan terhadap teori sains dan rumus matematik yang digunakan...ini lebih jelas dan mudah difahami...iya...mereka juga rajin juga bertanya minta disemak apa yang mereka dapat dengan saya sepanjang gerak kerja." TB06/G/F3KBK/NILAI/ AMIE/G01/B94

\title{
Kemahiran Mereka Cipta
}

\section{Berkomunikasi}

Pelajar Hawa menyatakan dalam temu bual, pembelajaran ini disifatkan sebagai suatu rancangan penyelesaian masalah untuk tugasan yang diberikan, pelajar menumpukan komunikasi kepada dua bahagian, pertama, komunikasi semasa perbincangan yang lebih tertumpu kepada kefahaman sendiri dan dalam kumpulan. Manakala, pelajar Jasman mengatakan bahawa komunikasi dalam perbincangan bertujuan untuk pemilihan laluan alternatif terbaik untuk isi kandungan pelaporan dalam bentuk pembentangan.

"Kami banyak kali bincang dalam kumpulan sebab ada yang kami balik-balik tidak faham kalau dalam kira-kira dan bagaimana mahu kasi bagus laporan." TB06/P/F3KBK/REKA/ HAWA/P04/B357

"Kami bincang untuk kasi pilih laluan yang final...dari apa yang kami bincang awal-awal, kami kasi susun dulu rangka skrip sama tambah isi baru. Kami bentang untuk semua orang dengar sama kena komen." TB06/P/F3KBK/REKA/ JASMAN/P06/B360

Guru Alice menyokong kenyataan pelajar dengan menyatakan bahawa semasa perbincangan kumpulan berlaku, ketua kumpulan menyampaikan rangka isi kandungan berulang-ulang dan memastikan pendengar faham isi kandungan pelaporan yang perlu disampaikan. Ini dilakukan untuk memastikan semua ahli mencapai kefahaman yang sama dalam kumpulan mereka. Selain itu, guru Jose berpendapat bahawa interaksi semasa perbincangan bukan sahaja tertumpu secara lisan malah, pelajar menyediakan pembentangan dalam bentuk slid PowerPoint untuk mempersembahkan pelaporan misi mencari dan menyelamat.

\begin{abstract}
"Komunikasi dilihat berlaku secara lisan dan bertulis ikut dalam bentuk tugasan yang diberikan. Tugasan diagihkan, dan pelajar kemudian bentang kepada semua ahli. Saya lihat pelajar cuba berkongsi sebaik mungkin supaya semua rakannya mencapai aras kefahaman dan kemahiran yang sama...sebab objektif yang sama perlu dicapai" TB06/G/F3KBK/REKA/ ALICE/G02/B154
\end{abstract}

"Mereka berusaha menghasilkan slide yang boleh dipersembahkan untuk semua faham untuk menjawab soalan tugasan dan saya rasa slide mereka berjaya buat orang yang dengar faham apa yang mereka cuba sampaikan"

TB06/G/F3KBK/REKA/JOSE/G04/B159

Dalam menyiapkan tugasan akhir, pelajar Nadia menyatakan bahawa cadangan pelaporan menerima kritikan daripada oleh ahli kumpulan yang lain dan dikomen oleh guru pembimbing. Pelajar menggunakan maklum balas ini untuk memperbaiki isi kandungan strategi misi mereka. Dan menurut pelajar Banny lagi, maklum balas daripada ahli kumpulan lain dan guru pembimbing secara dua hala ini bukan sahaja membantu memperkukuhkan isi kandungan pelaporan misi kumpulan malah, memberi keyakinan kepada pembentang untuk membentang laporan misi. 
Malaysian Journal of Social Sciences and Humanities (MJSSH), Volume 5, Issue 7, (page 32 - 50), 2020

DOI: https://doi.org/10.47405/mjssh.v5i7.444

“Ada yang tanya soalan dan komen pelan misi kami...kami rasa bagus juga, cikgu. Boleh kasi betul apa yang kami mungkin salah bah. Bagus juga lah. Kami terima saja." TB06/P/F3KBK/REKA/NADIA/P01/B411

"Bila sudah dikomen sama kena soalan, kami kasi bagus aturan isi kandungan terus. Bila bentang semula lebih yakin. Kami ada juga rujuk balik sama guru untuk kasi tambah apa-apa lagi yang perlu...” TB06/P/F3KBK/REKA/BANNY/P03/B414

Guru Hamie dan guru Alice mengiakan kenyataan pelajar ini bahawa pelajar menggunakan maklumat balas dalam bentuk makluman balas dan komen untuk menyemak mana-mana kesilapan yang berlaku, lantas memperbaiki isi kandungan dalam penyelesaian masalah yang dicadangkan untuk dibentangkan sebagai pelaporan akhir pelajar.

"Semakan dan refleksi dalam berbentuk perbincangan dua hala antara kumpulan dan guru pembimbing ini membantu pelajar untuk mencari mana yang perlu ditambah baik lagi, sebelum pelaporan final dibentangkan."

TB06/G/F3KBK/REKA/ HAMIE/G03/B216

"Kumpulan mereka memperbaiki susunan laporan dan isi kandungan selepas sesi soal jawab bersama rakan-rakan dan guru-guru."

TB06/G/F3KBK/REKA/ALICE/G02/B219

\section{Mengkonsepsikan}

Pelajar Hawa dan pelajar Fatin turut menarik perhatian pengkaji semasa temu bual, dengan menyatakan bahawa garapan kefahaman melalui pengetahuan dan kemahiran yang semakin baik sepanjang latihan membolehkan pelajar menghasilkan suatu rangka strategi misi yang sistematik. Ringkasan keseluruhan isi kandungan penyelesaian masalah bermula daripada gambaran mental yang terbina secara peringkat sepanjang fasa latihan sehingga terbina suatu konsep bermakna bagi pelajar melalui penghasilan tugasan fasa 3.

"Selepas habis sampai akhir ini perbincangan paling last baru jadi senang faham, cikgu, kami masukkan idea dalam 3 bahagian. Bahagian operasi robot, matematik dan sains sama apa kami mahu kasi tambah baik."

TB06/P/F3KBK/REKA/HAWA/P04/B215

"Untuk last tugasan sebenarnya kami faham kena ada satu konsep bah...apa cara mahu rancang itu misi, mesti tersusun...ok juga sebab ada sudah pengalaman kan...macam kami sudah atur misi ikut bahagian lepas kena bincang, kasi susun laporan supaya senang kasi explain masa pembentangan. "P/F3KBK/REKA/ FATIN/P05/B219

Guru Jose menyokong kenyataan yang pelajar meringkaskan konsep strategi misi dengan aplikasikan gambaran awal, rangka idea dan melalui penelitian secara berperingkat. Guru Alice berpendapat situasi menunjukkan perkembangan yang positif dari segi kefahaman dan penguasaan kemahiran oleh pelajar. Guru turut menjelaskan bahawa pelaporan akhir misi dimurnikan sebelum dirumuskan agar mudah untuk difahami apabila dibentangkan kepada pendengar.

"Penceritaan operasi untuk menyelamat juga rancang dengan pengetahuan yang terbina mula awal latihan. Saya perhatikan jika pelajar-pelajar dalam kumpulan ini boleh meringkaskan proses dengan langkah-langkah dengan tepat dan dijadikan suatu rumusan keseluruhan, maksudnya dia faham isi-isi penting yang perlu dia sampaikan.” TB06/G/F3KBK/REKA/JOSE/G04/B210 
DOI: https://doi.org/10.47405/mjssh.v5i7.444

"Untuk tugasan yang akhir, mereka mempamerkan kebolehan untuk merancang susunan pergerakan dan isi kandungan dalam pembentangan hasil tugasan sebagai satu pakej misi yang lengkap." TB06/G/F3KBK/REKA/ALICE/G02/B216

Pelajar Jasman dan pelajar Banny juga menyatakan gambaran mental awal yang jelas membantu pelajar memastikan kesinambungan dalam penceritaan strategi misi mencari dan menyelamat yang berlaku. Gambaran awal yang melibatkan rangka strategi penyelesaian misi ini dijanakan menjadi isi kandungan mengikut ciri-ciri maklumat yang relevan setelah dianalisis dan dinilai dan akhirnya, dimurnikan sepanjang latihan fasa 3.

"Masa mula latihan memang ada sudah bayang-bayang apa kami mahu buat, kami bincang bahagian A dengan B, idea mesti kena gabung sebab bila dikasi gabung baru semua plan cerita nampak bersambung."

TB06/P/F3KBK/REKA/JASMAN/P06/B425

"Apa yang mahu di kasi bentang memang plan kena bincang ikut gambaran awalawal masa bincang. Sudah ada pecahan soalan, kami bincang ikut pecahan sampai semua isi kandungan jadi laporan misi." TB06/P/F3KBK/REKA/ $B A N N Y / P 03 / B 429$

Guru Amie turut menyatakan bahawa pelajar sedar pentingnya mewujudkan kesinambungan antara isi kandungan cadangan pelan operasi dan strategi. Untuk memastikan kesinambungan isi kandungan ini, pelajar melakukan semakan isi kandungan agar selari dengan kehendak tugasan sejak mula dari idea asas lagi. Menurut guru Alice lagi, maklum balas diutamakan dan perbincangan dilaksanakan demi mencapai konsensus dalam penyelesaian masalah. Menurut guru, pelajar sangat berhati-hati dalam semakan untuk memastikan isi kandungan dapat menjawab kehendak tugasan terakhir fasa 3 ini.

"Semua idea dibincangkan dimurnikan dan digabungkan oleh pelajar. Semakan
banyak kali membantu pelajar untuk menjamin kesinambungan antara aspek
kemahiran sains matematik dan keperluan untuk menyelamat dan juga fakta sains
yang ada." TB06/G/F3KBK/REKA/ AMIE/G01/B456

"Gabungan idea didapati dengan bantuan maklumat dari semua ahli kumpulan dan dipersetujui oleh ahli...ketua kumpulan bertindak untuk pastikan semua idea didengar dan yang paling penting final hasil menjadi ringkas...tepat dan semua mudah faham" TB06/G/F3KBK/REKA/ ALICE/G02/B459

Pelajar Banny pada akhir fasa pembelajaran telah mengaplikasikan sumber maklumat yang ada untuk meringkaskan aspek penceritaan penyelesaian masalah teknikal dalam strategi misi yang dilaksanakan oleh kumpulan sebagai contohnya, pelajar memetik fakta dan fungsi robot yang terkini di pasaran untuk memudahkan penjelasan pelan strategi misi mereka. Pelajar Fatin mengakui bahawa konsep misi mencari dan menyelamat dapat disampaikan dengan baik apabila rangka penceritaan adalah sistematik dan logik. Kedua-dua pelajar ini menggunakan carta alir untuk memudahkan penyampaian pelan strategi misi serta cadangan penyelesaian masalah yang tersusun.

“...bila perlu explain teknikal robot...kami guna info robot terkini di website robot yang dijual untuk explain fungsi rekaan robot misi kumpulan. Kami rujuk rekaan yang betul-betul wujud" TB06/P/F3KBK/REKA/BANNY/P03/B462

"Apa yang kami sudah faham, paling bagus semua ini boleh kena kasi ringkas jadi satu pelan yang paling bagus. Terus... guna flow chart senang untuk kasi mudah semua orang faham." TB06/P/F3KBK/REKA/FATIN/P0/B479

Guru Hamie menyatakan bahawa untuk pelajar memastikan kejelasan konsep yang pelajar ingin ketengahkan dalam pelaporan. Manakala, Guru Alice menyatakan pelajar cenderung untuk 
menggunakan maklumat teknikal, dan saintifik yang boleh dicapai daripada sumber yang lain untuk membantu menonjolkan lagi aspek konsep yang pelajar ingin sampaikan.

"Pelajar guna contoh yang boleh menunjukkan konsep apa yang pelajar cuba ketengahkan. Saya rasa contohnya yang tepat sangat membantu kumpulan menjelaskan apa konsep misi kumpulan masing-masing." TB06/G/F3KBK/REKA/ HAMIE/G03/B481

"Pelajar bijak juga sebab pelajar menggunakan contoh konsep dan penyataan saintifik dan teknikal yang memang sudah wujud di pasaran atau di internet sebagai isi kandungan pelaporan misi dan penyelesaian masalah misi mereka, bagusnya nanti orang senang faham dan orang lain rujuk kemudian." TB06/G/F3KBK/REKA/ALICE/G02/B414

\section{Perbincangan}

\section{Reka Bentuk Pembelajaran STEM}

Kemahiran berfikir kritis adalah proses intelek yang berdisiplin dilakukan secara aktif dengan berkemahiran untuk membuat konsep, aplikasi, menganalisis, sintesis, dan atau menilai maklumat yang dikumpul atau dijana melalui pemerhatian, pengalaman, refleksi, penghujahan atau komunikasi sebagai panduan kepercayaan dan tindakan (Scriven \& Paul, 2007).

Sehubungan dengan definisi dan konteks kajian ini, pola perkembangan kemahiran berfikir kritis menunjukkan tiga komponen yang jelas iaitu, perkembangan elemen kemahiran menganalisis, menilai dan mereka cipta penyelesaian masalah dengan penguasaan disposisi elemen menganalisis, menilai dan mereka cipta. Kemahiran ini dapat dilihat dengan jelas sewaktu proses permulaan penjanaan maklumat dan penyemakan kesahihan maklumat serta komponen maklumat. Seterusnya, disposisi dominan dapat dilihat ketika pelajar menunjukkan keupayaan untuk mengaplikasi elemen kemahiran berfikir kritis untuk menilai maklumat lantas membuat keputusan dan mendorong tingkah laku serta tindakan sendiri. Akhir sekali, ketika pelajar menyelesaikan permasalahan yang dihadapi.

Dalam pembelajaran STEM berasaskan Robot ini, arahan eksplisit digunakan oleh guru sepanjang pembelajaran menyokong penguasaan kemahiran berfikir kritis terutamanya pada fasa kedua yang melibatkan pembelajaran yang lebih teknikal. Seperti yang dinyatakan oleh Abrami, Bernard, Borokhovski, Wade, Surkes, Tamim dan Zhang (2008), di mana arahan eksplisit dalam instruksional yang jelas adalah penting untuk menggalakkan prestasi pelajar.

Dapatan ini menunjukkan bahawa pelajar lebih cenderung memerlukan instruksional yang eksplisit dalam mengintegrasikan pembelajaran STEM yang fokus terhadap penerapan elemen berfikir kritis. Dan perlunya pengisian progresif gerak kerja yang sistematik, jelas dan mudah diikuti oleh pelajar. Instruksional yang mampu menimbangi kerumitan cabaran dengan pemudahcaraan proses pembelajaran sangat mempengaruhi kecenderungan pelajar untuk melibatkan diri secara lebih aktif dalam proses berfikir.

Walau bagaimana pun, adalah penting untuk dijelaskan di sini bahawa kajian ini tidak dapat melihat memastikan perkembangan setara untuk semua disposisi elemen kemahiran berfikir kritis pelajar. Ini dialami juga oleh kajian-kajian oleh Aizikovitsh-Udi dan Amit (2011), Qing, Ni dan Hong (2010), Ozturk, Muslu dan Dicle (2008) dan Miri et al. (2007), bahawa kekuatan dan kelemahan kemahiran berfikir pelajar melibatkan pengaruh dan saling hubung antara elemen secara keseluruhan, dan juga potensi serta kesan program yang telah dilaksanakan untuk membangunkan kemahiran berfikir mengikut elemen yang disasarkan (Tiwari, Lai \& So, 2006). Penemuan kajian seperti ini membantu kajian masa depan untuk mencuba membangunkan strategi pembelajaran yang lebih berkesan untuk meningkatkan semua elemen penting kemahiran Berfikir Kritis. 


\section{Penyelesaian Masalah}

Menurut Barell (2006), kemahiran berfikir kritis, penyelesaian masalah, kolaboratif dan kreatif adalah sangat diperlukan dalam kesinambungan kehidupan sebenar untuk membantu melakukan penyelesaian masalah dengan baik. Seperti yang dibincangkan terdahulu dan berpegang kepada sokongan kajian yang lepas, pembelajaran STEM berasaskan robot dengan tugasan penyelesaian masalah telah memberi peluang dan ruang kepada pelajar untuk mempraktikkan elemen kemahiran berfikir kritis dalam persekitaran kolaboratif, dan dalam konteks permasalahan dunia sebenar.

Pelajar dalam kajian ini aktif melibatkan diri dalam penyelesaian masalah melalui tugasan khususnya tugasan berkumpulan yang melibatkan pembinaan dan persaingan gerakan kawalan robot. Di samping mengembangkan kemahiran penyelesaian masalah secara analitikal mengikut kemampuan perkembangan minda pelajar itu sendiri. Ini sekali lagi disokong oleh Tarmizi dan Bayat (2011) di mana pelajar dalam aktiviti berasaskan masalah bukan sahaja aktif menghayati usaha penyelesaian masalah malah, aktif mengembangkan kemahiran penyelesaian masalah pada masa yang sama.

Melihat dalam konteks kajian ini, peningkatan penguasaan pengetahuan sains dan matematik yang sedia ada dengan pengetahuan baharu menerusi aplikasi kemahiran berfikir secara sistematik dalam proses penyelesaian masalah. Dalam program latihan ini, pelajar mempunyai kebebasan dan ruang untuk menemukan cadangan penyelesaian masalah dalam cara serta pendapat pelajar itu sendiri. Ini selaras dengan kajian Mertz (2006), di mana permasalahan yang perlu dilihat daripada pelbagai sudut masalah serta memerlukan aplikasi teknik dan praktikal penyelesaian yang pelbagai contohnya, laporan misi penyelamatan mangsa bencana kebakaran bangunan dalam pertandingan robot.

Kajian ini telah menyediakan pelajar permasalahan yang terbuka kepada pelbagai cara penyelesaian masalah. Bermula daripada fasa 1, 2 dan 3, memberi kebebasan untuk pelajar untuk mengolah penyelesaian masalah mengikut acuan pelajar sendiri selagi menjadi praktikal dan terbukti berjaya mencapai objektif tugasan. Memetik laporan Hussain et al. (2006), pelajar dalam kajiannya telah menggunakan strategi cuba jaya yang lebih popular untuk menyelesaikan masalah. Kejadian yang sama berlaku dalam kajian ini, pelajar melakukan strategi cuba jaya untuk penyelesaian masalah kerana pelajar cenderung menggunakan pengetahuan yang sedia ada, pengalaman dan praktikal dalam latihan secara berulang sepanjang fasa latihan. Ini kerana pelajar lebih yakin untuk menerima dan dipersembahkan idea penyelesaian masalah mengikut pola padanan kejayaan dan penggunaan formula yang terjamin berjaya akhir fasa latihan.

\section{Kesimpulan}

Secara keseluruhannya, pembelajaran STEM berasaskan Robot (Outside of School Time) di luar waktu sekolah sangat berpotensi menyokong perkembangan elemen kemahiran berfikir kritis menganalisis, menilai dan mereka cipta penyelesaian masalah melalui penguasaan disposisi kemahiran berfikir kritis secara spesifik mula menunjukkan perkembangan yang positif dengan pada masa yang sama menyokong penguasaan pengetahuan dan kemahiran sains dan matematik melalui pengalaman yang dilalui. Disposisi dominan elemen kemahiran berfikir kritis yang dikesan sepanjang pembelajaran STEM berasaskan robot melalui penyelesaian masalah melibatkan elemen menganalisis yang melihat pelajar cenderung mengenal pasti maklumat yang diperlukan berdasarkan ciri-ciri pelajar menggunakan ciri-ciri maklumat yang disasarkan untuk membina urutan keutamaan untuk mendapatkan rangka awal dalam menyelesaikan masalah teknikal yang dihadapi. Sementara itu, untuk elemen menilai pelajar berupaya untuk mencadangkan cadangan penyelesaian awal diselaraskan dengan penilaian terhadap gangguan teknikal di lapangan berdasarkan maklum balas dan wajaran justifikasi dan akhirnya untuk elemen mereka cipta, pelajar cenderung untuk melakukan penyusunan rangka kepada konsep penyelesaian masalah menerusi pengalaman dan maklum balas untuk penambahbaikan dalam penyelesaian masalah yang diperlukan. 


\section{Rujukan}

Anwari, I., et al. (2005). Implementation of Authentic Learning and Assessment through STEM Education Approach to Improve Students' Metacognitive Skills. K-12 STEM Education, 1 (3), p.123-136.

Asmuniv. (2015). Pendekatan Terpadu Pendidikan STEM Upaya mempersiapkan Sumber Daya Manusia Indonesia yang Memiliki Pengetahuan Interdisipliner untuk Menyongsong Kebutuhan Bidang Karir Pekerjaan Masyarakat Ekonomi ASEAN (MEA). Retrieved from:

Biggs, J., \& Tang, C. (2007). Teaching for quality learning at university. Berkshire, UK: Open University Press.

Chow Fook Meng. (2005) "Jendela kelabu: Pendekatan kualitatif dalam kajian tindakan." In Kertas Kerja yang dibentangkan dalam Seminar Penyelidikan Pendidikan, pp. 25-27.

DeJarnette, N. K. (2012). America's children: Providing early exposure to stem (science, technology, engineering, and math) initiatives. Education, 133(1), 77-84.

Facione, P. A. (1990). Critical Thinking: A Statement of Expert Consensus for Purposes of Educational Assessment and Instruction. Research Findings and Recommendations.

Halpern, D. F. (1998). Teaching critical thinking for transfer across domains: Disposition, skills, structure training, and metacognitive monitoring. American Psychologist, 53(4), 449.

http://www.vedcmalang.com/pppptkboemlg/index.php/menuutama/listrik- electro/1507-asv9.

Jones, G., Dana, T., LaFramenta, J., Adams, T. L., \& Arnold, J. D. (2016). STEM TIPS: Supporting the Beginning Secondary STEM Teacher. TechTrends. https://doi.org/10.1007/s11528-016-0052$\underline{5}$

Kek, M. Y. C. A., \& Huijser, H. (2011). The power of problem-based learning in developing critical thinking skills: preparing students for tomorrow's digital futures in today's classrooms. Higher Education Research \& Development, 30(3), 329-341.

Kelley, T.R., \& Knowles, J.G. (2016). A Conceptual Framework for Integrated STEM Education (versi elektronik). International Journal of STEM Education, 3 (11), p.1-11.

Kennedy, T.J. \& Odell, M.R.L. (2014). Engaging Students In STEM Education. Science Education International, 25(3), p.246-258.

Lin, Y. (2014). Infusion of critical thinking into L2 classes: a case study in a Chinese high school, (January), 315. Retrieved from https://theses.ncl.ac.uk/dspace/handle/10443/2377.

Maria Salih \& Nurulhuda Abd Rahman. (2013). Pendekatan Pemikiran. Dalam Nurulhuda Abd Rahman. \& Md Nasir Ibrahim. (eds.). Pemikiran Kritis dan Kreatif: konsep, Pendekatan dan Aplikasi dalam Pengajaran dan Pembelajaran. (pp. 1-21). Universiti Pendidikan Sultan Idris.

Mulnix, A. B., Vandergrift, E. VH. (2014). Tipping point in STEM education. Journal of College Science Teaching, 43(3), 14-16.

Paul, R., \& Elder, L. (2009). The miniature guide to critical thinking concepts \& tools. Dillon Beach, CA: Foundation Critical Thinking.

Swartz, R. J., \& Parks, S. (1994). Infusing the Teaching of Critical and Creative Thinking into Content Instruction: A Lesson Design Handbook for the Elementary Grades. Critical Thinking Press and Software, PO Box 448, Pacific Grove, CA 93950-0448.

Willingham, D. T. (2008). Critical thinking: Why is it so hard to teach?. Arts Education Policy Review, 109, 21-32. 